\title{
Church, narrative, community and identity in times of migration
}

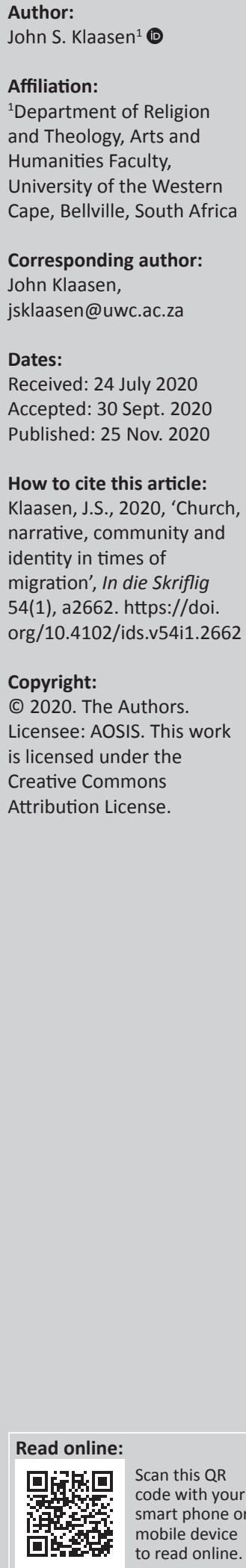

Migration is perceived by many communities as a threat to national unity, social cohesion, nationality or common identity. This article is an attempt to address the following question: How does or should the church as a narrative community respond to migrants? Within the South African context, xenophobic attacks and protests directed to migrant workers are two of the visible phenomena which seem to suggest that migrants are an important social phenomenon for peaceful co-existence. I will investigate the church as a narrative community and its role towards migrants. The identity of the church is situated within a narrative and the care towards migrants is influenced by this narrated community.

Keywords: narrative; church; identity; immigration; migration; the other; xenophobia; narrative; church community; eucharist.

\section{Introduction}

How does or should the church as a narrative community respond to migrants? Migration is perceived by those in power as one of the most threatening social factors to the global community. The threat of losing national identity, disturbing monocultural societies, the uncertainties of the unknown and migration involves the loss of identity, meaning, familiarity and economic sustainability. This four-pronged loss is a perceived threat to world peace and the future of the generations to come:
... the presence on South African soil of so many immigrants from all over the world and the implications of their presence in the job market, as well as the problem of the country's scarce resources, raise controversial comments and debates. One notion, or unsubstantiated belief held by many South Africans, is that immigrants from north of the country's borders are taking South Africans jobs. (Kalitanyi \& Visser 2010:376)

The xenophobic violence that took place in South Africa in 2008 is a manifestation of the perceived losses of a segment of the population. There has been many more recent reports of xenophobic attacks and threats in the newspapers and other official reports. Whilst many of these reports have focussed on the physical violence against immigrants, few have reported on the sufferings that displacement brings to the strangers and the landless:

Displacement is about disorientation and the existential pain of transition. In the migrant and refugee crisis people have been forced out of their 'natural habitat' and have become strangers in a strange land in which the social and political codes are difficult to read. (Louw 2019:218)

It is not only the migrants that experience a sense of loss, but also the host nation. 'Immigration has inevitably a destabilizing impact on the constellation of traditional views on what a nation and citizenship is about' (Louw 2016:3). Xenophobic attacks and the destabilisation of communities should be critically engaged with, so that the complexity of migration is problematised.

I will investigate the church as a narrative community and its role towards migrants. Narrative is the movement of capacity building and agency making to critically engage distorted meanings of identity and meaning making. The church community is a narrative community where migrants challenge the construction of their own identity and that of the church community.

\section{Narrative and identity}

There has been a growing interest in narrative in disciplines such as psychology, development studies, religion, theology, history and sociology. Whilst this contribution seeks to add to the corpus of literature about the use of narrative in theology, I will draw on the use of narrative in psychology. In the field of theology, the biographical outline of narrative is comprehensively 
recorded in publications such as L. Gregory Jones', 'Art Narrative Theology', (1993); Bernd Wacker's Narratieve theologie? (1977); George Stroup's The promise of narrative (1981); and Theology and narrative: A critical introduction (1982).

\section{Smit (1990) maintains that:}

Party narratiewe teoloë sal sê dat 'n mens die vraag wie 'n mens is, of wie 'n groep mense is, dit wil sê vraag na die identiteit van mense of van groepe van mense, veel beter kan beantwoord deur stories oor die mens of mense [te] vertel, as deur filosofiese, logiese definisies te probeer gee [Some narrative theologians claim that the question who you are or who a group is, can be answered much better by telling stories about people than giving philosophical, logical definitions] (p. 110 [author's own translation])

In his works such as Vision and Virtue (1981), and other publications such as The Peaceable Kingdom: Primer in Christian ethics (1983), the influential Christian ethicist, Hauerwas, illustrates the correlation between identity and narrative. Identity, for Hauerwas, is about agency and character that is formed by narrative in a community. Identity is not so much about one universal phenomenon such as reason, but about what we accurately learn from the community:

Appeals of agency as a characteristic of the self cannot in principle guarantee our 'freedom'. All determination, since our very ability to know what we have done and to claim our behaviour as our own is dependent on the descriptions we learn. There is no contradiction between claims and sociality, since the extent and power of any agency depends on the adequacy of the descriptions we learn from our communities ... our ability to 'have character' does not require the positing of a transcendental freedom, rather it demands a recognition of the narrative nature of our existence. The fundamental category for ensuring agency, therefore, is not freedom but narrative (Hauerwas 1983:43)

According to Hauerwas, to know the self is to place the narrative of the self in the broader narrative of God. Narrative shows the self and the rest of the world as creatures dependent on God. Narrative also places the self as a historical being with other beings and therefore the self is inextricably linked with the community. God's revelation, Jesus Christ and his relationship with the church mirrors the covenant relationship of God and the people (Klaasen 2012:109-110). This history is the narrative of the church.

This history is told in a certain kind of community. Deeply influenced by John Howard Yoder's critique of philosophical ethics, Hauerwas (2007:151) asserts that the church is an alternative politics'. He (Hauerwas 1983) further claims that what differentiates Christians:

... is a willingness to belong to a community, which embodies the stories, the rituals, and others committed to worshipping God. Such a community, we believe, must challenge our prideful pretentions as well as provide the skills for the humility necessary for becoming not just good, but holy (p. 35)

The self is not an atomistic, absolute independent reduced to a single phenomenon such as reason; instead, the self is transformed and formed within 'the presence of others'. Agent, referring to identity, is a person who has the capability
'... to be called from myself to another' (Hauerwas 1983:45). The self is not created by its own independence, but the interdependence of the self and the other. In this sense, freedom is not more independence, but the kind of relationship of mutual trust that fosters mutual enrichment and reciprocal development. Interdependence is not biological in nature like the kind we find between parent and child, but from a theological perspective, the sacrament of baptism makes people free and connected as equals (Hauerwas 2012:300).

Müller, an African theologian and one of the foremost narrative theologians in our day, embeds identity in narrative. Identity is beyond the visible, biological and autonomous individual. As he shifts from the socially constructed approach to the postfoundationalist approach to theology, Müller asserts that narrative leaves identity fluid, changeable and dynamic. The postfoundationalist approach places the self in a relationship with the other that influences the self. Müller (2011) claims that:

The postfoundationalist approach forces us to listen firstly to the stories of people in real life situations. It does not aim to describe merely a general context, but confronts us with a specific and concrete situation. (p. 3)

Further, quoting Van Huyssteen (2006:10), Müller (2011:3) writes that persons, as:'... embodied persons, and not abstract beliefs, should be seen as the locus of rationality. We, as rational agents, are thus always socially and contextually embedded'.

Using research as an example, Müller (2017:88) asserts that the story of the researcher overlaps with the researched matter, and that this perceived state of weakness becomes the strength of the researcher. Müller opines that a narrative approach takes a poststructuralist position. To emphasise the interconnectedness of the self with the knowledge about the subject, Müller (2017) quotes Richardson and St. Pierre (2005:962):

... knowing the self and knowing about the subject are intertwined, partial, historical local knowledges ... This position also draws the researcher into the dynamics of an ever-changing and fluid identity. Narrative research does not leave one unchallenged or unchanged. (p. 88)

Like Hauerwas, Müller contends that the self is not static or unchanged. The self is not restricted to one identifiable constant like abstract reason. The self is constructed in a community with a narrative. The self is contextually formed and has the capability of discerning what the values and morals of the community are. Both Hauerwas and Müller regard agency as constitutive of self. The self is not about abstract and dogmatic beliefs, but consists of both being and doing. Both Hauerwas and Müller claim that community is indispensable for identity, although Hauerwas' community is less open than Müller's community. Nevertheless, the self is interdependent with the other and regards the other (coresearcher and presence of the other) as identity forming and 
meaning making. Both academic scholars shifted from liberal individualism to communitarianism.

\section{Narrative and community}

Narratives and community are interweaved. The community finds identity through the narratives that are told, shared, and applied. Whether an individual or group, identity is formed within the community who finds commonality in the narratives of the community. Citing Stroup (1984:133), Meylahn (2003) asserts the claim that a community uses its narratives to understand its past, experiences, historical events, visions and dreams:

A community is a group of people who have come to share a common past, who understand particular events in the past to be of decisive importance for interpreting the present, who anticipate the future by means of a shared hope, and who express their identity by means of a common narrative. (p. 122)

A community is inextricably connected with common experiences that are embedded in the narrative. As such, the community comprises the common experiences that are delineated by symbols, rituals and habits; the community is also open to growth, enrichment and potentialities. When community is linked to narrative, the constants of the community are fluid, flexible and organic (growth). Community is a space and place where:

The self is never in isolation, but as a social being develops in interaction. The self is neither above the community nor suppressed through subordination or coerced into an identity that is alien to the self. The self becomes in relation to other selves chooses the good as the self in relationship with other selves (Klaasen 2012:113)

The individual is not alienated or dominated by the community, but grows through mutual and reciprocal enrichment. The self is not absolute independent, but narrative provides the opportunity to transcend the boundaries of division and separation. By imagination, I refer to the suspension of the fixed atomistic individual to discover new creative images of the self: what can I look like, be like, act like, or become like? Ricoeur (in Fodor 1997:157) advances for a break in the engagement so that a secondorder continuity can take place. I contend that identity is in continuous formation and takes place within a community of selves who relate to a narrative. Freeman (2014) rightly maintains that:

Rather than thinking of narrative mainly in terms of its orientation to the past, I have tried to suggest that it bears upon the future as well: the process of rewriting the self is at one and the same time a process of articulating the self-to-be, or the self that ought to be. At the same time, rather than thinking of narrative mainly in terms of this category of the self. I have tried to suggest that narrative is also very much about the other-than self, about the ends-and the goods-that are operative in the process at hand ... the category of the Other is primary; that is, it comes before the self. (p. 13)

Both narrative and community have the interconnection of past, present and future as a continuum. Time is not necessarily linear, but a process of looking back and forth that gives meaning to the experiences of the community with the idea of who we ought to be. The excerpt below from the story of a poor blind man from the famous South African Truth and Reconciliation hearing, illustrates the power of telling stories:

Ms Gobodo-Madikizela: Baba, do you have any bullets in you as we speak? Mr Sikwepere: Yes, there are several of them. Some are here in my neck. Now on my face you can really see them, but my face feels quite rough, it feels like rough salt. I usually have terrible headaches. Ms Gobodo-Madikizela: Thank you, Baba. Mr Sikwepere; Yes, usually I have a fat body, but after that I lost all my body, now I am thin, as you can see now. Ms Gobodo-Madikizela: How do you feel, Baba, about coming here to tell us your story? Mr Sikwepere: I feel what -what has brought my sight back, my eyesight back is to come back here and tell my story. But I feel what has been making sick all the time is the fact that I couldn't tell my story. But now I - it feels like I got my sight back by coming here and telling my story (Krog 1998:30-31)

Telling the story in the presence of the other, whether the other is part of my community or not, is the opportunity to create a liberating future. Moreover, telling the story provides the space to make sense of one's experiences and gives meaning to the lived experiences that would otherwise have eluded the self and the potential to get one's sight back. Fodor (1997) avows:

In short, it is through the act of narrating that we learn how to negotiate our world, acquiring - as we tell and retell our most determinative stories - a certain ethical dexterity, a particular finesse in our moral judgements. (p. 157)

The past is indispensable to the formation of the self. Whilst the past does not have to remain absolutely the same, it does inform the present and the future. What kind of past informs the present? Historical facts that remain unchanged, perpetuate an unchanged present, having less potential for a dynamic creative future. Conversely, a narrated past that is told through different selves, opens new possibilities for growth and enrichment. In this regard, Taylor (1992) contends:

To the extent that we move back, we determine what we are by what we have become, by the story of how we got there ... And as I project my life forward and endorse the existing direction or give it a new one, I project a future story, not just a state of the monetary future but a bent for my whole life to come. This sense of my life as having a direction towards what I am not yet is what Alasdair McIntyre captures in his notion ... that life is seen as a 'quest'. (p. 48)

Selves have the unique ability to expand beyond the immediate boundaries. The future is both to be explored and in the making. 'In the making' refers to the agency of humans to respond to the different alternatives or options that the future presents. Selves can shape the future by identifying alternatives or options and responding with the maximum information about the future. Van den Berg and Ganzevoort (2014) proclaim that:

... our expectations for the future are to a high degree performative by nature. We create a future in as much as we try to predict it. This may seem problematic in light of the scientific 
ideal of objectivity, but it fits quite nicely in a more constructionist epistemology. More than that it allows us to develop desirable future scenarios. (p. 169)

We have the two tensions of past and future, and self and the other. These two tensions are not mutually exclusive or antagonistic. They function in a creative tension that is interlinked to expand the horizon and transcend the present state of identity. The interconnectedness of the community and narrative creates the space and time for the moments, pauses, suspension or weaving of truthful identity. The other becomes the trigger that causes the self to gaze and see the self for who the self is created to be.

\section{Migrant, the other and identity}

Migration refers to both human and non-human movement. Although many definitions of migration abound, it generally refers to the movement of humans from one place to another and, in this case, from one country to another because of economic, social, political, religious or environmental reasons. The main reasons for migration in the last decade have been the destabilising of countries and nations because of wars, economic hardships and political intolerance. A nuanced and broad definition of migration that I will use for this study is the movement of people across country ... lines within the African continent for the purpose of establishing a new place or seeking peace and stability' (Kalitanyi \& Visser 2010:377).

The number of immigrants grew considerably from 6545 in 2002 to 142800 in 2013. This indicates a 39\% increase between 2003 and 2013. More than half of the number are from other parts of Africa. 'This number of migrants has to be taken as an estimate because the number of migrants to South Africa between 1994 and 2001 ranges between 2.5 and 5.0 million. However, the number of migrants from South Africa exceeds $5.0 \mathrm{~m}$ (it is estimated to be up to $9.0 \mathrm{~m}$ ) (Consortium for Refugees and Migrants in South Africa 2008)'. In 2010, the number of immigrants totalled $7 \%$ of the country's population of $54.4 \mathrm{~m}$. This phenomenal increase in migration within Africa is contrary to popular belief that migration from Africa is towards Europe. 'The problem is that such ideas are based on assumption, selective observation or journalistic impressions rather than on sound empirical evidence' (Flahaux \& De Haas 2016:2). These assumptions are fuelled by sensationalist to attach the African continent to human trafficking, boat overcrowding that leads to deaths at sea and drug trafficking. There are currently about $4.2 \mathrm{~m}$ immigrants and 300000 refugees from Zimbabwe in South Africa (Laczko \& Appave 2013). Although data and studies to determine the number of immigrants varies and differs greatly, the rapid increase of immigrants to South Africa became the focus of attention with the rise of xenophobic attacks in 2008. It was reported that, during that time, at least 67 people were killed and 670 were wounded. In addition, approximately 150000 people were displaced from where they lived, resulting in some families being split, depending on their safety and available accommodation. Within a few weeks, millions of rands of damage was caused to property that either belonged to or was rented by foreign nationals (Segatti \& Landau 2011:10). More recent protests, such as the protest of truck drivers over the employment of foreign drivers from other parts of Africa, is another depiction of the conflict between South Africans and non-South Africans. Headlines such as 'Interdict granted against truck driver strike over employment of foreign nationals' (News24 07 July 2020) is indicative of the perceived threat that immigrants pose for citizens of South Africa. In response to the xenophobic attacks of 2008, Hansen, Jeannerat and Sadouni (2009:187) asked the question that underlies the fear, violence, suspicion and alienation of South African inhabitants: 'How can one make a legitimate claim to being a part of South African society ... Who can be a fully entitled citizen, and who shall remain a temporary migrant and visitor?'

For the most part, the conflict was not about economic opportunities or the provision of health facilities, but it was about who might lay claim to the resources and opportunities. It was about identity. Timber (2005:3 in Kalitanyi \& Visser 2010:367) maintains that, instead of competing for economic opportunities and scarce resources, immigrants create jobs and even provide jobs for South Africans. The following story illustrates the many successes among immigrants in South African:

Bezuidenhoud (2000:5) reports that it is not too long ago that a Nigerian immigrant, Michael Inegbese, was selling potato chips on a pavement near Cape Town's central taxi rank. Just five years later, the 35-year-old accountant, who arrived in South Africa in search of a better life, owned a successful business selling cell phones and accessories in a city-centre shop. Now he is house-hunting: 'I am looking to buy property, maybe get married'. He is also about to start an Internet café, and hopes to increase the number of his SA employees from five to ten. (Kalitanyi \& Visser 2010:382)

A comprehensive study by the Organization for Economic Co-operation and Development and International Labour Organization (OECD/ILO) (2018) concluded:

That foreign-born individuals can positively affect the fiscal balance of a developing economy. In both 2001 and 2011, foreign-born workers contributed more than they received under the two alternative scenarios for the respective years ... In comparison, revenue collection from the native-born population covered slightly more than the value of public expenditure in 2001

Both migration policies and conflict between migrants and the host people is not necessarily about economic and social benefits, but about identity. It is about how migrants affect the nature, norms and values of a nation. If migrants are regarded as a threat to the identity of a host nation, then there will always be potential for conflict. Whereas if migrants are perceived to add value to identity formation, then the presence of migrants is opportunity for truthful identity and peaceful co-existence of difference without separation. It is my contention that religion can facilitate the peaceful existence of migrants and host nations. The church, as the 
embodiment of the mission of God, can provide the space and time for people characterised by differences without separation. The church through its narrative of suffering and redemption does mission when it tells the story of Jesus Christ who was born, raised, died and resurrected in order that all humanity may live in a mutually enriching relationship with each other, with the non-human community and with God. The church tells a narrative that expands horizons, transcends differences and weaves barriers into a fluid, flexible whole.

\section{The church, narrative and identity}

The church understands its identity by the stories that have been passed down and retold within the community. It is from these stories that the gathered community derives their identity. Christians draw from the narratives of the church to make their experiences intelligible and give meaning to their behaviour and actions. To give meaning to his beliefs, Cone (1975) rightly refers to the story of the church - the story of Jesus Christ:

If someone ask me, Jim, how can you believe? What is the evidence of truth? My reply is quite similar to the testimonies of the Fathers and Mothers of the Black Church: let me tell you a story about a man called Jesus who was born in a stable in Bethlehem. He went throughout ... Galilee preaching that the Kingdom is coming, repent and believe the gospel. The Kingdom is the new creation where the hungry are fed, the sick healed and the oppressed liberated. It is the restoration of humanity to its wholeness. This man was killed because of his threat to the order of injustice. But he was resurrected as Lord, thereby making good god's promise to bring freedom to all who are weak and helpless ... All I can hope or wish to do is to bear witness to it, as this story leads me to openness to other stories. (pp. 116-119)

The story of Jesus is told and retold by different people in various ways on different occasions and in different forms. The facts might not remain the same, but the impact, the formation of the teller and the hearer takes place. The story of Jesus and the story of the church gives meaning to questions like 'who are we?' or 'who am I?' The Christian story answers some of the questions which the cosmological story cannot answer. It is precisely because the church uses an open-ended story to make sense of where persons come from and how persons came into being that the church has a unique contribution to make during times of crises such as migrancy.

This is further supported by Conradie (2008) when he stresses that:

God's work may be understood as a narrative, and immense story, a drama. Christianity is essentially a historical religion. The God of Christianity is a God of history ... Christian faith may be understood not as a set of beliefs or propositions, but as an attempt to capture the meaning of the story, to discern the presence of God in history from within our particular situation as it is embedded in history. Accordingly, the church is a storyshaped and story-telling community and Christian worship is the continued recital, proclamation and celebration of this story through which the 'dangerous memory' (JB Metz) of the passion of Jesus Christ is kept alive. Telling the story is both an act of remembrance and, since the story is still unfinished, also of anticipation. (p. 29)

The Christian story is relived in the drama of the Eucharist. The Eucharist is a sacrament that depicts God's work through Jesus Christ in the world. The Eucharist is a gathering of people or a community who listens to the story of Christ's passion and resurrection, and are thereby reminded of their agency, of their identity. The Eucharist is an assembly of those who by their baptism participate in the narrative that confirms their calling in the church and the world. Zizioulus, a prominent Orthodox theologian, regards the ecclesia as the divine body where personhood (identity) is formed. God is person and personhood in the identity of humans. This implies that humans are not individuals, but are formed in relationship with each other. The other is primary for the formation of the person. For Zizioulas, the community, where personhood is formed, is the ecclesia. Personhood entails a relationship with God, the other and the rest of creation. 'Personhood implies the freedom to be oneself, it means the freedom of being the "other" and the freedom to live with the "other"' (Otu 2012:58), and:

... this freedom is not freedom from the other but freedom for the other. Freedom in this case becomes identical with love. God is love because he is Trinity. We can love if we are persons, that is if we allow the other to be truly other, and yet in communion with us. (Zizioulus 1994:17)

Three derivations can be made from divine personhood. Firstly, the person develops identity through relationship; secondly, freedom is freedom with the other and from the other; and thirdly, personhood is creative when it comes to creating the Other (Micallef 2019:229-230).

The mission of the ecclesia is faithfulness to God's mission which is embedded in community and, according to Hauerwas and Zizioulus, in a specific ecclesial community. Those who participate in this community adopt an identity that derives from the telling of the narrative that the community gets its identity from. The identity of the community and its members are not absolute, static or unchangeable. The identity is formed whenever one tells and hears the narrative of the church. The narrative of the church makes sense of the particular experiences through the past. The narrative also points to the future, and the plot of the narrative is never fully realised as absolutely complete. The ecclesial narrative draws the hearers and the teller of the narrative into moments of pause and imagination, which raises the following question: Who ought I to be?

\section{In conclusion, some markers for the church's response to migration}

Migrants are not a threat to the identity of persons or communities. The church's narrative welcomes migrants as the other. Those who participate in the narrative of the church, 
share a common narrative that makes their experience intelligible. The open-ended narrative of the church welcomes the migrants as the other who provides the pause in the identity of the host nation. This does not mean that the identity of the hosts is threatened to dissolve or to be discarded as a false identity. A pause of identity is what Ricoeur refers to as mimesis - an accrual of an action or conduct's meaning (Fodor 1997:155). The pause is an action that extends the identity of both the hosts and the migrants into a greater sense of identity.

Through symbols and metaphors, the Christian story is in a better position than the cosmopolitan story, because it is not limited to the lived objectified experiences. The architecture, symbols, rituals and metaphors that form part of the ecclesia are means to the transcendence of the lived experiences and objective meaning. The other draws the self into a non-static state with mutually enrichment as the constant.

The plot of the church's narrative is the content of mission towards the migrants. Salvation of all people as the core mission priority of the church is freedom for the other and self. It is not freedom from migrants, but freedom for migrants. Freedom does not imply self-realisation, but to be in communion with one's hosts. Freedom in the sense of the mission of the church does not mean difference that leads to alienation or isolation. Freedom means that difference exists and is acknowledged within connectedness and interdependence.

The church's narrative brings different narratives together through its critical engagement with its own narrative. The church's narrative is not only about remembering, but also about what is in the making and 'in anticipation' (Conradie 2008):

There is a crossing over from the one to the other as well as continuation. In such an understanding of narrative, the one does not dominate the other, but two narratives engage critically to form morality. (Klaasen 2012:115)

The narratives of the migrants are lifegiving moments for both the host people and the migrants. Their stories are not absolute or timeless, but the narratives give meaning in the new particular that they find themselves in.

The Christian community is one of agency. The identity of the community is not restricted to being. Being and doing is inextricably bound in the narrative of the church. The church is faithful to the narrative of Jesus Christ when it exercises its agency as affirmed by the baptism and ordination within the community - a common narrative. Baptism is a calling to participate in the narrative - telling and doing of the church. In baptism, being and doing are the hallmarks of identity. With these hallmarks, being and doing, there is continuity of the plot.

The agency is not any effort to be involved with migrants, but it is a particular type of agency that was formed within the church community. Such agency is aware that the self is not absolute independent, but that interaction with migrants is both a calling and a vocation. Agency is the gift to know the narrative rather than the ability to do according to one's own strength.

\section{Acknowledgements Competing interests}

The author declares that he has no financial or personal relationships which may have inappropriately influenced him in writing this paper.

\section{Authors' contributions}

I declare that I am the sole author of this research article.

\section{Ethical consideration}

This article followed all ethical standards for carrying out research.

\section{Funding information}

This research received no specific grant from any funding agency in the public, commercial, nor not-for-profit sectors.

\section{Data availability statement}

Data sharing is not applicable to this article as no new data were created or analysed in this study.

\section{Disclaimer}

The views and opinions expressed in this article are those of the author and do not necessarily reflect the official policy or position of any affiliated agency of the author.

\section{References}

Cone, J., 1975, God of the oppressed, Seabury Press, New York, NY.

Conradie, E., 2008, 'The earth in God's economy: Reflections on the narrative of God's work', Scriptura 97(2008), 13-36. https://doi.org/10.7833/97-0-711

Consortium for Refugees and Migrants in South Africa, 2008, viewed 18 October 2020 from https://documentcloud.adobe.com/link/track?uri=urn $\% 3$ Aaaid $\% 3$ Ascds $\% 3$ AUS\%3A1c1a168d-5a1f-4cd6-a2e4-b13cef097a3d\#pageNum=1 Consortuim for refugees and migrants in South Africa report.

Flahaux, M.L. \& De Haas, H., 2016, 'African migration: Trends, patterns, drivers', Comparative Migrant Studies 4(1), 1-25. https://doi.org/10.1186/s40878-015 0015-6

Fodor, J., 1997, 'The tragic face of narrative judgement: Christian reflections on Paul Ricoeur's theory and of narrative', in J. Morny (ed.), Paul Ricoeur and narrative: Context and contestation, pp. 153-174, University of Calvary Press, Alberta.

Freeman, M., 2014, 'Narrative, ethics, and the development of identity', Narrative Works: Issues, Investigations and Interventions 4(2), 8-27. https://doi.org/10.7202/ 1062097ar

Hansen, T.B., Jeannerat, C. \& Sadouni, S, 2009, 'Introduction: Portable spirits and itinerant people; Religion and migration in South Africa in a comparative perspective', African Studies 68(2), 187-197. https://doi.org/10.1080/00020180903109565

Hauerwas, S., 1981, Vision and virtue, University of Notre Dame, Notre Dame, IN.

Hauerwas, S., 1983, Peaceable kingdom: Primer in Christian ethics, University of Notre Dame Press, Notre Dame IN.

Hauerwas, S., 2007, The state of the university: Academic knowledge and the knowledge of God, Blackwell Publishing, Oxford.

Hauerwas, S., 2012, 'Remembering how and what I think: A response to the JRE articles on Hauerwas', Journal of Religious Ethics 40(2), 296-306.

'Interdict granted against truck driver strike over employment of foreign nationals', News24, 07 July, 2020, viewed 15 July 2020, from https://www.news24.com/ news24/southafrica/news/.

Jones, G.L., 1993, 'Art narrative theology' in A.E. McGrath (ed.), The Blackwell encyclopedia of modern Christian thought, pp. 395-398, Blackwell, Oxford. 
Kalitanyi, V. \& Visser, K., 2010, 'African immigrants in South Africa: Job takers or job creators?', South African Journal of Economic and Management Sciences 13(4) creators?', South African Journal of Economic and
376-390. https://doi.org/10.4102/sajems.v13i4.91

Klaasen, J., 2012, 'Open-ended narrative and moral formation', Acta Theologica 32(2), 103-124. https://doi.org/10.4314/actat.v32i2.7

Krog, A., 1998, Country of my skull, Random House South Africa, Johannesburg.

Laczko, F. \& Appave, G. (eds.), 2013, World migration report 2013: Migrant wellbeing and development, International Organization for migrants, Geneva.

Louw, D., 2016, 'The refugee dilemma and migrant crisi: "Charity begins at home" or "Being home to the homeless"? The paradoxical stance in pastoral caregiving and the infiltration and perichoresis of compassion', HTS Teologiese Studies/ Theological Studies 72(2), 1-11. https://doi.org/10.4102/hts.v72i2.3267

Louw, D., 2019, 'Human displacement as challenge to pastoral caregiving. Towards a hermeneutical design for an existential and diagnostic approach to ecclesial welcoming', Stellenbosch Theological Journal 5(1), 217-238.

Meylahn, J., 2003, 'Towards a narrative theological orientation in a global village from a postmodern urban South African perspective', PhD thesis, University of Pretoria.

Micallef, J., 2019, 'Communion as otherness in Zizioulus' theology of personhood as basis for true otherness, identity and unity', Sophia XI(2), 221-245.

Müller, J.C., 2011, 'Postfoundational practical theology for a time of transition', HTS Teologiese/Theological Studies 67(1), 1-5. https://doi.org/10.4102/hts. v67i1.837

Müller, J.C., 2017, 'African foundational practical theology', Acta Theologica 37(1), 86-96. https://doi.org/10.18820/23099089/actat.v37i1.6

OECD/ILO, 2018, How immigrants contribute to South Africa's economy, OECD, Paris. http://dx.do.org/10.1787/9789264085398-en
Otu, I., 2012, 'The eco-theologies of Thomas Berry and John Zizioulus: Intimations for ecological justice', MA thesis, Toronto, Toronto School of Theology.

Richardson, L. \& St. Pierre, E.E., 2005, 'Writing: A method of enquiry,' in N.K. Denzin \& Y.S. Lincoln (eds.) The Sage handbook of qualitative research 3rd edn., pp. 959-977, Sage, London.

Segatti, A. \& Landau, L.B. (eds.), 2011, Contemporary migration to South Africa: A regional development Issue, The International bank of Reconstruction and Development/The World Bank, Washington, DC.

Smit, D., 1990, “"Prof Nico” se storie ...oor narratiewe teologie, herinneringe en hoop', in M. Hofmeyr, K. Kritzinger \& W. Saayman (eds.), Wit Afrikane? In gesprek met Nico Smith, pp. 110-127, Taurus, Bramley.

Stroup, G., 1981, The promise of narrative, John Knox, Atlanta, GA.

Stroup, G., 1982, Theology and narrative: A critical introduction, Abington Press, Nashville, TN.

Stroup, G., 1984, The promise of narrative theology, SCM Press, London.

Taylor, C., 1992, Sources of the self: The making of the modern identity, Cambridge University Press, Cambridge.

Timberg, C., 2005, Refugees with hopes, skills find opportunity in South Africa, Foreign service A21, Washington Post.

Van den Berg, J.A. \& Ganzevoort, R.R., 2014, 'The art of creating futures - Practical theology and a strategic research sensitivity for the future', Acta Theologica 34(2), 166-185. https://doi.org/10.4314/actat.v34i2.10

Van Huyssteen, J.W., 2006, Alone in the world: Human uniqueness in science and theolog:. The Gifford lectures, W.E. Eerdmans, Grand Rapids, MI.

Wacker, B., 1977, Narratieve theologie? Kösel, München.

Zizioulus, J.D., 1994, 'Communion and otherness', Sobornost 16(1), 7-19. 